\title{
Article \\ Examining Perceived Entrepreneurial Stress: A Causal Interpretation through Cross-Lagged Panel Study
}

\author{
Tahseen Arshi ${ }^{1, *(\mathbb{D})}$, Qazi Kamal ${ }^{2}$, Paul Burns ${ }^{3}$, Veena Tewari $\left.{ }^{4}{ }^{(}\right)$and Venkoba Rao ${ }^{4}(\mathbb{D}$ \\ 1 School of Business, American University of Ras Al Khaimah, Ras Al Khaimah 86416, UAE \\ 2 Leeds Business School, Leeds Beckett University, Leeds LS1 3HE, UK; k.qazi@leedsbeckett.ac.uk \\ 3 School of Business, University of Bedfordshire, Bedfordshire LU1 3JU, UK; paul.burns@beds.ac.uk \\ 4 Business Faculty, Majan University College, Muscat 112, Oman; veena.tewari@majancollege.edu.om (V.T.); \\ venkoba.rao@majancollege.edu.om (V.R.) \\ * Correspondence: tahseen.arshi@aurak.ac.ae
}

Citation: Arshi, T.; Kamal, Q.; Burns, P.; Tewari, V.; Rao, V. Examining Perceived Entrepreneurial Stress: A Causal Interpretation through Cross-Lagged Panel Study. J. Open Innov. Technol. Mark. Complex. 2021, 7, 1. https:// dx.doi.org/10.3390/joitmc7010001

Received: 1 December 2020

Accepted: 16 December 2020

Published: 22 December 2020

Publisher's Note: MDPI stays neutral with regard to jurisdictional claims in published maps and institutional affiliations.

Copyright: (c) 2020 by the authors. Licensee MDPI, Basel, Switzerland. This article is an open access article distributed under the terms and conditions of the Creative Commons Attribution (CC BY) license (https: / / creativecommons.org/ licenses/by/4.0/).
Abstract: The entrepreneurial stress construct's nomological validity is not well established as past studies have not delineated between entrepreneurial and employee stress. This study investigated several entrepreneurship-specific stressors positing their causal effect on perceived entrepreneurial stress (PES). It examined four directional hypotheses testing the causal, reverse, reciprocal relationships and moderation effects between stressors and PES. Further, it looked at the moderating impact of psychological capital. More than 300 entrepreneurs in emerging markets, namely India, Pakistan, and the United Arab Emirates, participated in this longitudinal study (Time $1 n=325$, Time 2 $n=310)$. The study adopted a cross-lagged competing model research design and analyzed the data using structural equation modeling (SEM). The results show that entrepreneurship-specific personal, social, and occupational stressors cause PES. Further, the results also support the reverse causal effect of PES on stressors and a reciprocal relationship. The study advances resource-based theory to an entrepreneurial background, highlighting the role of intangible resource gaps in perceived entrepreneurial stress. The study concludes that entrepreneurship-specific intangible resources are useful to entrepreneurs at personal, social, and occupational levels. An actual or perceived loss of these resources may lead to perceived entrepreneurial stress. Furthermore, PES can interfere with the entrepreneurial capacity for innovation over time. Psychological capital can be an effective coping response as a moderator of perceived entrepreneurial stress' adverse effects. This is one of the first studies that examines PES in an emerging market context, specific to entrepreneurial employment.

Keywords: perceived entrepreneurial stress; stressors; open innovation; psychological capital; resource-based theory; cross-lagged panel study; emerging markets; structural equation modeling

\section{Introduction}

Stress is a complex phenomenon comprising stressors, perceived stress, and strain [1]. Perceived stress is a psychological reaction to the uncontrollability and unpredictability of life and work pressures [2]. Gorgievski and Stephan [3], Maritz [4], and Shepherd [5] supported the view that stress interacts with a person's psychological conditions and produces a deviation from normal functioning. Conceptual unification of the entrepreneurial stress construct continues to pose a challenge to researchers as past studies have presented a weak articulation of stress' complex nature [6]. Lerman et al. [7] found that entrepreneurial stress research is marked with ambiguity, contradictory results, and almost non-existence of a unified theoretical framework in their meta-study. The stress appraisal theory [8] is critiqued due to subjectivity in stress appraisal as the responsibility of stress assessment is put on the individual. Further, entrepreneurial stress research is not well disentangled from employee stress literature $[4,9,10]$. The identified stressors among salaried employees have minimal relevance in an entrepreneurial context [9]. The studies conducted so far 
have not adequately captured the entire range of stressors from an entrepreneurial and psychological perspective [11]. Little knowledge exists on the causal interaction between stressors and perception of stress and the role of any moderation effects.

The context of emerging markets has not been considered while examining perceived entrepreneurial stress [12,13]. Kortum et al. [14] explained that the expert knowledge to deal with stress in emerging markets is not on par with developed markets. Clough [15] further highlighted that the scarcity of resources and socio-economic conditions' vulnerability enhances stress. Resource gaps can compromise entrepreneurial capacity towards innovation, typically known to suffer due to resource constraints in emerging markets [16]. Perceived entrepreneurial stress (PES) can interfere with entrepreneurial decision making and critical competencies related to innovation $[17,18]$. Further, volatility in emerging markets can result in the loss of resources valued by entrepreneurs. According to Hobfoll et al. [19], vulnerability to loss of valuable resources psychologically affects entrepreneurial wellbeing. The need to explore, test, and validate entrepreneurial stressors unique to an entrepreneurial job in emerging markets motivates the rest of this paper.

Cardon and Patel [20] and Uy et al. [21] linked entrepreneurial stressors to entrepreneurial work characteristics, arguing that stress is an inescapable accompaniment to entrepreneurial venturing. Risks, lack of organizational structure, personal responsibility, passion, immersion in business, withdrawal from society, financial and emotional investment, and limited security guarantees differentiate entrepreneurial careers from salaried employees $[16,22,23]$. The study adopted a resource perspective to understand PES. Therefore, it leveraged one of the most influential theories-resource-based view (RBV) [24]. RBV can explain differences in performance through valuable and non-substitutable resources $[24,25]$. This study argued that personal, social, and occupational resources are useful to entrepreneurs, the loss of which can create PES. The study examined entrepreneurial stressors through several cross-lagged competing models postulating directional hypotheses. In doing so, it looks at the causal, reversed, and reciprocal relationships between them. Frese [26] argued that longitudinal studies are best suited to examine revered and mutual effects. Secondly, it looked at the moderating role of psychological capital between stressors and perceived entrepreneurial stress.

This study is conducted in India, Pakistan, and the United Arab Emirates because these emerging markets have demonstrated an accelerated path towards entrepreneurial development [27]. These emerging markets are breeding grounds for new entrepreneurs, and their experiences are appropriate for examining entrepreneurial stress. The volatility and downward pressure in oil prices have made emerging markets more dependent on entrepreneurship growth [28]. Entrepreneurship development is a significant governmental plan aimed at the diversification of the United Arab Emirates economy. India and Pakistan are vigorously pushing the entrepreneurial agenda to deal with rising unemployment [29]. There has been substantial growth in these countries' entrepreneurial ecosystems over the last few years, characterized by unsupported high-risk venturing [30]. Further, resource constraints and low institutional quality characterize emerging markets. In such a scenario, entrepreneurial stress is more likely to prevail because individual job expectations may be contrary to their expected outcomes. These are more likely to intensify as environmental stressors develop. Entrepreneurship in this research environment is driven either through a government incentive or a lack of adequate resources. In such a melting pot of entrepreneurial activities, entrepreneurial stress is more likely to occur and can be actively captured.

\section{Theoretical Background}

Resource-based view (RBV) theory, which evolved from resource-based theory (RBT), forms a basis to understand and cope with entrepreneurial stress. RBV theory has seen multiple variations in its conceptualization. Barney et al. [31] argued that RBV theory could be invigorated through a fresh resource-based inquiry in different contexts and expand its linkages with multiple disciplines. Further, Barney [32] argued that RBV should consider 
all critical resources (tangible and intangible) that allow firms to generate value. A crucial issue in the application of RBV theory to an entrepreneurship context is the relevancy of resources to the entrepreneurial background both at the organization and individual level [33]. Considering that PES can be subjective, a resource-based perspective can show the factual effects of resource gaps and resource loss, in the light of which perceptual lens can be more effective. Collins [34] and Sameera [35] argued that a resource portfolio comprises both resources and capabilities, matching the organizational needs. Entrepreneurial firms need to make decisions under uncertainty and make risky resource commitments. Arguably, scarcity or loss of valuable resources can contribute to entrepreneurial stress [19]. Entrepreneurial firms' resource needs may differ from those of large firms [36,37]. Considering a weak demarcation between entrepreneurial life and work, a heterogeneous view of entrepreneurial resources can extend the application of RBV theory to entrepreneurial firms.

Interestingly, in a meta-study, Sameera [35] found that the majority of resource applications of RBV referred to individual resources. According to Alonso [38], intangible resources such as personal, social, and occupational resources and capabilities become critical in an entrepreneurial context. These intangible resources are valuable and non-substitutable [4], and hence RBV's application in understanding PES is appropriate. The study applies RBV theory to emerging markets, typically known for economic adversity, and providing a differential advantage of resource position to entrepreneurs [39]. It argues that such stressors aggravate entrepreneurs who work against resource-constrained backgrounds.

\section{Review of Literature and Hypothesis Development}

Entrepreneurial stress researchers such as Lerman et al. [7], Rauch et al. [40], and Stephan [41] argued that several challenge and hindrance stressors at the individual and organizational level create perceived stress among entrepreneurs. Hindrance stressors are typically characterized by an underlying resource and capability constraint, particularly those that entrepreneurs consider valuable to their wellbeing [19]. Cognitively driven stressors create a gap between entrepreneurs' perceptions and actual outcomes [42].

\subsection{Personal Stressor: Capability Gap}

According to Aure et al. [43] and Tran and Korflesch [44], perceived expectations drive entrepreneurial inclination to develop entrepreneurial careers. Tahir [45] suggested that perceived stress occurs when there is a discrepancy between expectations and capabilities to meet job demands. From a resource perspective, entrepreneurs are expected to perform multiple roles, but they have limitations to their abilities. Ebbers and Wijnberg [46] and Baikadi [47] explained that entrepreneurs take responsibility for various tasks, which keep evolving as the new venture takes shape and starts to grow. The job demand resource (JD-R) model explains that stress affects the imbalance between the existing capabilities, resources and job demands. Multiple roles place a higher demand on entrepreneurs and lessen their capabilities to perform [48-51]. Generally, entrepreneurs emotionally connect to their ventures, and hence, any results that are contrary to their expectations creates entrepreneurial stress [52,53]. Entrepreneurs show a desire for high achievement, and when their ambitious goals are unfulfilled, it can create perceived entrepreneurial stress [54].

\subsection{Social Stressor: Social Life Gap}

As the entrepreneurial job demands increase, entrepreneurs' social life quality decreases [55-57]. Entrepreneurial employment demands immersion in the business and commitment to unrealistic deadlines. Personal difficulties and scarcity of resources lead to loneliness and less time for socialization [58-60]. Toyin [61], Hemle et al. [62], and Keyes [63] argued that an entrepreneur's perception of autonomy and control associated with entrepreneurial employment suffers as the quality of social life deteriorates [61,64]. According to Koe [65], innate psychological needs act as nutrients for social life quality. Once 
again, from a resource viewpoint, time, energy, and socialization opportunities become scarce resources for entrepreneurs, and thus lead to stressful conditions $[66,67]$.

\subsection{Occupational Stressor: Stability Gap}

Another significant characteristic of an entrepreneurial job is the imperativeness of risktaking [68,69]. Risk-taking is often more intense for entrepreneurs than salaried employees, where the risk is mostly the organization's onus. Entrepreneurs make risky decisions, which provokes anxiety until the outcomes are known [70]. Perceptions of stability suffer under resource constraints and resource volatility, which are typical of emerging markets [71]. Barney [72] argued that monetary benefits, significantly associated with innovation, cannot be ascertained due to uncertainties and risks. The higher the risk appetite of entrepreneurs, the greater the return. In such situations, risk management capability becomes a vital resource to develop risk resilience in uncertain conditions [73]. As risks increase, risk management capability becomes strained, leading to an entrepreneurial desire for stable conditions. However, entrepreneurs need to compete, exploit opportunities, innovate, and learn, which requires risk-taking, and hence stability continues to elude entrepreneurs, leading to PES.

\subsection{Psychological Capital}

Researchers have argued that psychological capital (PsyCap) can play a vital role in dealing with entrepreneurial stress [74]. Depending on the psychological capital's strength, it can moderate entrepreneurial stress [75,76]. Peterson et al. [77] noted, "Psychological capital provides individuals with the confidence to undertake challenging tasks ... and to show resilience after failures". Hope, self-efficacy, optimism, and resilience are critical factors that make up PsyCap [78,79]. Kamal and Daoud [80] found that self-efficacy is a crucial factor that helps reduce the fear of failure. Similarly, Salisu [81] and Reivich and Shatte [82] found that resilience is a vital resource for entrepreneurs' success in emerging markets. Furthermore, resourcefulness is theorized to form a nomological component of this construct $[83,84]$. Resourcefulness enables entrepreneurs to deal with resource constraints in emerging markets. The study argues that since entrepreneurial stress has a psychological lineage, a psychological response is appropriate. Furthermore, given the psychological capital's ability to moderate entrepreneurial pressure, it becomes an essential and useful resource for entrepreneurs.

\subsection{Gaps in the Existing Literature}

The literature has several research gaps related to entrepreneurial stress. Firstly, the combined effect of stressors specific to entrepreneurial employment is not adequately analyzed. Secondly, stressors are not viewed from an intangible resource perspective, particularly in resource-constrained environments, the loss of which can lead to PES. Thirdly, the temporal relationship between stressors and PES is unexplored. Finally, the literature does not comprehensively explain the moderating effects of psychological capital as a PES coping mechanism. The study framed four directional hypotheses addressing these gaps in the literature.

Hypothesis 1 (H1). A combination of personal, social, and occupational stressors has a causal effect on perceived entrepreneurial stress over time.

Hypothesis 2 (H2). Perceived entrepreneurial stress has a reversed causal impact on personal, social, and occupational stressors over time.

Hypothesis 3 (H3). Perceived entrepreneurial stress and personal, social, and occupational stressors have a reciprocal impact over time.

Hypothesis 4 (H4). Psychological capital moderates the relationship between personal, social, and occupational stressors and perceived entrepreneurial stress over time. 


\section{Materials and Methods}

The study adopted a quantitative research approach using structural equation modeling (SEM). Hair et al. [85] recommend the use of SEM to examine multiple and interrelated relationships and examine hypotheses. The study utilized IBM's Statistical Package for Social Sciences (SPSS) and its add-on module Analysis of Moment Structures (AMOS version 22) for data analysis. Further it also used the lavaan package for data analysis [86].

\subsection{Measures and Questionnaire Development}

In all, 29 items related to four factors of stress predictors were utilized through a structured questionnaire (Table 1).

Table 1. Measures and scales.

\begin{tabular}{lllll}
\hline Stressor Category & Stressor & Items & Adapted From & Alpha \\
\hline Personal stressors & Capability gap & 7 & Perceived stress scale [2,87] & $(\alpha=0.79)$ \\
\cline { 2 - 5 } & Achievement gap & 5 & $\begin{array}{l}\text { Achievement motivation } \\
\text { scale [88] }\end{array}$ & $(\alpha=0.71)$ \\
\hline Social stressors & Social life gap & 6 & $\begin{array}{l}\text { Social wellbeing scale [63] } \\
\text { satisfaction with } \\
\text { life-scale [89] }\end{array}$ & $(\alpha=0.81)$ \\
\hline Occupational stressor & Stability gap & 6 & Risk scale [70] & $(\alpha=0.84)$ \\
\hline Psychological capital & (moderator) & 5 & $\begin{array}{l}\text { Psychological capital } \\
\text { questionnaire [90] }\end{array}$ & $(\alpha=0.87)$ \\
\hline
\end{tabular}

Five-point Likert scale statements (5 strongly agree and 1 strongly disagree) anchoring 29 items in the questionnaire were used for data collection. Since questionnaires were self-reported, six items used the reverse scoring technique to ensure that questions were appropriately answered.

\subsection{Participants}

Questionnaires were sent to entrepreneurs who had started their ventures in the last two years (2017 onward). The list of entrepreneurial contacts was drawn from the MicroEnterprise Association in India, Small and Medium Enterprise Development Authority (SMEDA) in Pakistan, and databases from various chambers of commerce in the UAE. Entrepreneurs were chosen based on their responses to an email asking them if they have experienced stress. Data were collected through a two-wave (time lag of 1 year) panel survey between February 2019 (T1) $(n=325)$ and February 2020 (T2) $(n=310)$. There were approximately 150 participants from India, 75 from Pakistan, and 85 from the UAE.

There was no evidence of any low item-level response rate. Appropriate steps were followed during the survey planning stage to improve the response rate. Heeding to Baruch and Holtom's [91] suggestion, the survey instruments clearly articulated the research objectives, followed ethical guidelines, and improved transparency by informing the respondents how the results would be reported.

\subsection{Analytical Procedure}

The study first examined the temporal relationship between stressors and entrepreneurial stress. In accordance with the hypotheses, four cross-lagged panel SEM models were developed for empirical testing. Hakanen et al. [92] and Draugalis et al. [93] argued that through longitudinal data, temporal effects (T1 and T2) could be assessed through casual and reverse causal models.

Model 1, diagrammed in Figure 1, tested the respondents' relative standings of the constructs between time 1 (T1) and time 2 (T2). Selig and Little [94] suggested examining the autoregressive effects of the variables to reduce bias in the estimation of cross-lagged effects. The causal relationship was tested through model 2, which examined the causal 
impact of stressors on PES. Model 3 tested the reverse causal impact of PES on stressors, while model 4 assessed the reciprocal effects of stressors and PES. Autoregressive effects were added to all four models. Moderation effects were tested by positioning the moderator variable as an independent and interaction variable, as suggested by Baron and Kenny [95].

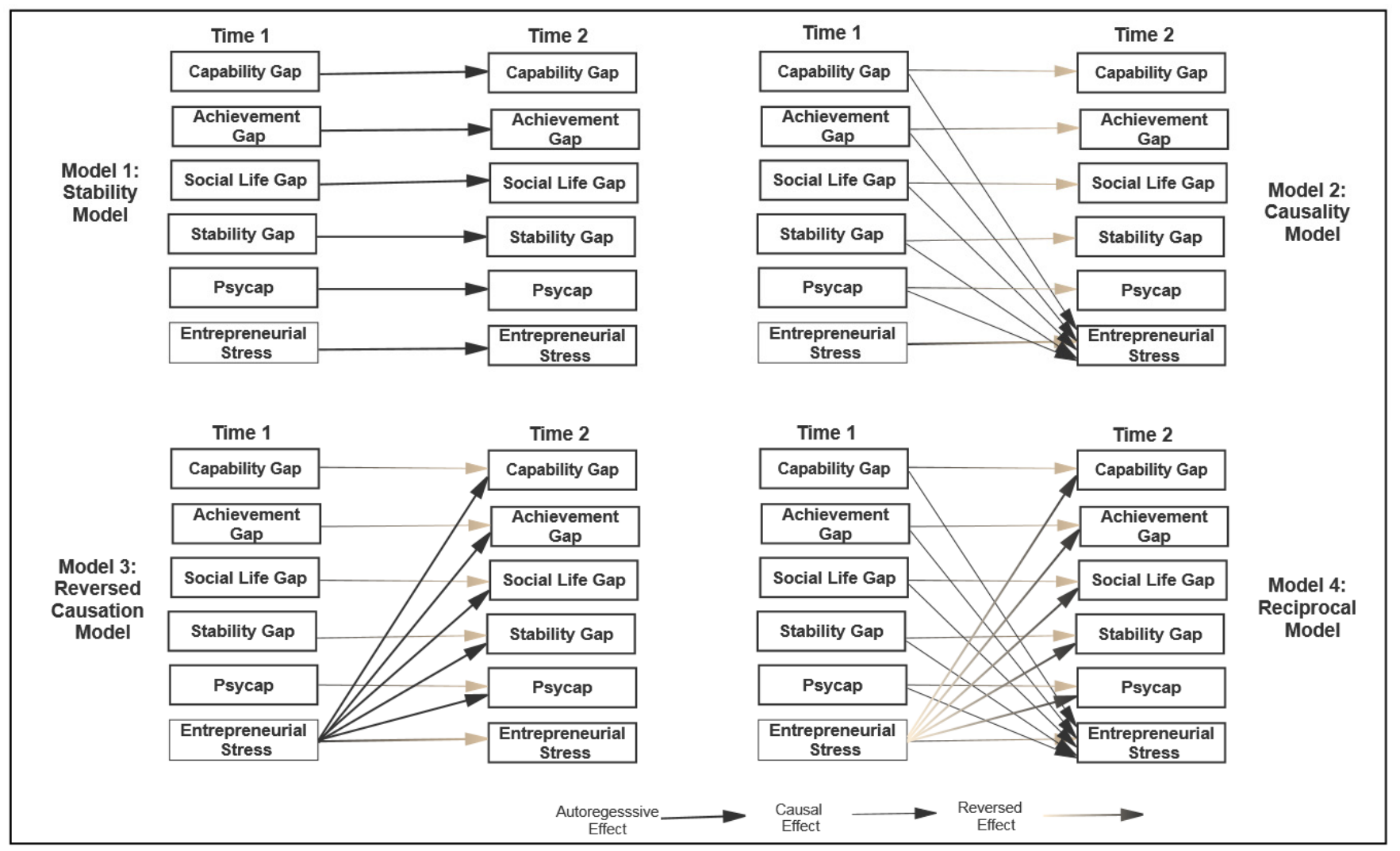

Figure 1. Competing Models.

Based on the suggestions of $\mathrm{Hu}$ and Bentler [96] and Kenny et al. [97], the results were compared to the thresholds of comparative fit index (CFI $\geq 0.95)$, Tucker-Lewis index (TLI $\geq 0.95$ ), root mean square error of approximation (RMSEA $\leq 0.05$ ), and $\chi^{2}$-difference test to detect the best-fitting model.

\section{Results}

Table 2 presents the demographic profile of the respondents based on the first phase of data collection.

Table 2. Demographic profile of respondents.

\begin{tabular}{|c|c|c|c|c|}
\hline Age & Gender & Education & Income (USD) & Industry \\
\hline $20-29$ years- $47 \%$ & Male $83 \%$ & Primary-6\% & $<20,000-41 \%$ & Trading-37\% \\
\hline 30-39 years-28\% & Female & Secondary $-7 \%$ & $21,000-30,000-32 \%$ & Hospitality-18\% \\
\hline $40-49$ years- $17 \%$ & $17 \%$ & Higher Secondary- $42 \%$ & $31,000-40,000-17 \%$ & $\begin{array}{l}\text { Pharmaceuticals-10\% } \\
\text { Real estate- } 8 \% \\
\text { Construction-12\% } \\
\text { Food- } 10 \%\end{array}$ \\
\hline $50-59$ years- $8 \%$ & & $\begin{array}{l}\text { Graduation-38\% } \\
\text { Post-Graduation-7\% }\end{array}$ & $>41,000-10 \%$ & Transport- $5 \%$ \\
\hline
\end{tabular}


Table 3 presents the mean, standard deviation, and correlations at $\mathrm{T} 1$ and $\mathrm{T} 2$.

Table 3. Descriptive and Pearson correlations matrix (T1) and Pearson correlations matrix (T2).

\begin{tabular}{|c|c|c|c|c|c|c|c|c|c|}
\hline Variable & Time & Mean & Std Dev & CPG & AHG & SLG & STG & PES & Psycap \\
\hline \multirow[t]{2}{*}{$\mathrm{CPG}$} & $\mathrm{T} 1$ & 3.916 & 0.723 & & & & & & \\
\hline & $\mathrm{T} 2$ & 3.842 & 0.789 & - & & & & & \\
\hline \multirow[t]{2}{*}{ AHG } & $\mathrm{T} 1$ & 4.094 & 0.693 & 0.081 & - & & & & \\
\hline & $\mathrm{T} 2$ & 4.081 & 0.714 & 0.079 & - & & & & \\
\hline \multirow[t]{2}{*}{ SLG } & $\mathrm{T} 1$ & 4.013 & 0.705 & $0.128^{* *}$ & 0.105 & - & & & \\
\hline & $\mathrm{T} 2$ & 4.010 & 0.771 & $0.119^{* *}$ & 0.114 & - & & & \\
\hline \multirow[t]{2}{*}{ STG } & $\mathrm{T} 1$ & 3.977 & 0.805 & $0.148^{*}$ & 0.032 & 0.059 & - & & \\
\hline & $\mathrm{T} 2$ & 3.912 & 0.824 & $0.147 *$ & 0.031 & 0.057 & - & & \\
\hline \multirow[t]{2}{*}{ PES } & $\mathrm{T} 1$ & 4.040 & 0.766 & 0.119 * & 0.059 & 0.122 ** & $0.196^{* *}$ & - & \\
\hline & $\mathrm{T} 2$ & 4.035 & 0.775 & $0.116^{*}$ & 0.059 & $0.222 * *$ & $0.195^{* *}$ & - & \\
\hline \multirow[t]{2}{*}{ Psycap } & $\mathrm{T} 1$ & 3.709 & 0.818 & -0.031 & -0.036 & -0.064 & 0.035 & $-0.330^{* *}$ & - \\
\hline & $\mathrm{T} 2$ & 3.804 & 0.804 & -0.030 & -0.036 & -0.061 & 0.034 & $-0.327^{* *}$ & - \\
\hline
\end{tabular}

$\mathrm{T} 1=$ time $1, \mathrm{~T} 2=$ time $2, n=325,{ }^{*}$ correlation is significant at the 0.05 level, ${ }^{* *}$ correlation is significant at the 0.01 level. CPG: capability gap, ACG: achievement gap, SLG: social life gap, STG: stability gap, ES: entrepreneurial stress, PsyCap: psychological capital.

The correlations were significant for several factors and in agreement with the hypotheses. Except for the achievement gap, all predicted stressors such as capability, social, and stability gaps showed significant positive correlations with PES (T1 $\mathrm{r}=119,122,196)$ $(\mathrm{T} 2 \mathrm{r}=116,222,195)(p<0.01)$. The stressors also correlated among themselves. Logically, the capability gap was positively correlated with the social life gap (T1 r = 128, T2 119, $p<0.01)$. As the capability gap increases, it demands more immersion in business, increasing the social life gap. The stability and capability gap were positively correlated, assuming they have a common underlying resource-capability nexus (T1 $\mathrm{r}=-148, \mathrm{~T} 2 \mathrm{r}=-147$, $p<0.01$ ). As capability gaps increase, risk management capability would decrease, leading to a heightened perception of stability gap. Finally, PsyCap was negatively correlated with PES (T1 $r=-330, T 2-327, p<0.01$ ). This association is in line with the hypothesis, which assumes that as PsyCap would strengthen, PES would reduce.

Since the correlations were significant, the data were tested for multicollinearity based on Tabachnik and Fidell's [98] recommendations. The variance inflationary factor values were $<0.2$, confirming that there were no inflationary effects on the data. Homoscedasticity, as suggested by Hamsici and Martinez [99], was further examined. A value of $>0.5$ (Levene's statistic test) and the presence of a single column result through Tukey's Honestly Significance Difference (HSD) test confirmed the sample's homogeneity.

\subsection{Measurement and Structural Models}

Structural equation modeling (SEM) was chosen as an appropriate data analysis technique because of its ability to determine relationships between latent and observed variables [85]. SEM was chosen because it allowed conclusions to be drawn from the hypothesized relationships [98,100]. The study conducted a confirmatory factor analysis by developing a measurement model to confirm the theoretical structure, as suggested by Kline [101]. As per the measurement invariance requirements, factor loading and intercepts were held equal, while items were allowed to correlate across time. In the measurement model, 21 out of 29 items associated with their factor structures (shown in Table 3) showed factor loadings $>0.55(p<0.001)$ and were retained, while eight items were removed due to insignificant scores. These 21 items were tested after an interval of one year administered through the questionnaire to the same set of respondents. Table 4 shows factor loadings, internal reliability (alpha), and average variance extracted (T1 and T2). 
Table 4. Factor loadings, alpha scores, and average variance extracted values.

\begin{tabular}{|c|c|c|c|}
\hline Items Used in the Questionnaire & Factor Score & Standard Alpha & $\begin{array}{c}\text { The Average Variance } \\
\text { Extracted }\end{array}$ \\
\hline \multicolumn{2}{|l|}{ Capability gap } & \multirow{4}{*}{$0.78(0.75)$} & \multirow{4}{*}{$0.5215(0.5314)$} \\
\hline Unclear comprehension of the role as an entrepreneur & $0.69(0.66)$ & & \\
\hline The gap between perceived and actual capabilities & $0.60(0.64)$ & & \\
\hline The gap between expected and actual outcomes & $0.63(0.59)$ & & \\
\hline \multicolumn{2}{|l|}{ Achievement gap } & \multirow{5}{*}{$0.82(0.79)$} & \multirow{5}{*}{$0.5458(0.5625)$} \\
\hline 1. Inability to achieve high self-actualization needs & $0.61(0.56)$ & & \\
\hline Failure to achieve ambitious goals & $0.64(0.57)$ & & \\
\hline Loss of passion for the job and optimistic outlook & $0.68(0.67)$ & & \\
\hline Loss of belief in an internal locus of control & $0.69(0.64)$ & & \\
\hline
\end{tabular}

Social life gap

1. Loss of social meaningfulness in life

2. Loss of satisfaction with life due to low social acceptance

3. Loss of social actualization

4. Loss of ability for social contribution

5. Low quality of work-family balance

\begin{tabular}{l}
$\frac{0.68(0.69)}{0.69(0.70)}$ \\
\hline $0.71(0.69)$ \\
\hline $0.67(0.71)$ \\
\hline $0.71(0.73)$
\end{tabular}$\quad 0.78(0.76)$

$0.5724(0.5614)$

Stability gap

1. Lack of stable health conditions

2. Lack of a sound financial position

3. The pressure to work in uncertain conditions

4. Lack of resources to maintain stability

5. Continuous pressure due to unpredictable outcomes

\begin{tabular}{l}
$\frac{0.64(0.62)}{0.70(0.67)}$ \\
\hline $0.68(0.62)$ \\
\hline $0.74(0.70)$ \\
\hline $0.76(0.71)$
\end{tabular}

Psychological Capital

1. Show self-efficacy and ability to solve problems

2. Remain optimistic even in the face of failure and risks

3. Show resilience despite adverse outcomes

4. Show resourcefulness despite limited resources

\begin{tabular}{l}
\hline $0.74(0.74)$ \\
\hline $0.73(0.76)$ \\
\hline $0.76(0.74)$ \\
\hline $0.77(0.79)$ \\
\hline
\end{tabular}

The measurement model at both time intervals showed a good fit to the data; T1 $\left(\chi^{2}(231)=342.03, p<0.01 ; \mathrm{CFI}=0.963 ; \mathrm{TLI}=0.957 ; \mathrm{RMSEA}=0.043\right)$ and $\mathrm{T} 2\left(\chi^{2}(231)=342.03\right.$, $p<0.01$; CFI $=0.963 ;$ TLI $=0.957$; RMSEA $=0.043)$. The data established the convergent validity of the four-factor PES through the measurement model. Factor scores associated with social life gap and stability gap showed higher factor scores, indicating their critical role in creating PES. This indicates that respondents gave higher importance to social and occupational resource gaps than personal resource gaps, perhaps because they have lower control. Similarly, PsyCap measures also showed high factor scores indicating their strong association with PES. The average variance scores $(>0.5)$ established the measures' discriminant validity, paving the way to conduct the structural test.

\subsection{Assessment of Competing Models and Hypotheses Testing}

The study performed a comparative assessment of all four competing path models to determine the model fit and test the hypotheses (Table 5). 
Table 5. Model comparison.

\begin{tabular}{|c|c|c|c|c|c|c|c|c|c|}
\hline$\#$ & Model & $x^{2}$ & df & CFI & TLI & RMSEA & Model Comparison & $\Delta \chi^{2}$ & $\Delta \mathrm{df}$ \\
\hline 1 & Stability model & 27.43 & 12 & 0.973 & 0.952 & 0.046 & & & \\
\hline 2 & Causality model & 11.45 & 9 & 0.992 & 0.988 & 0.044 & 1 vs. 2 & $26.91^{* *}$ & 3 \\
\hline 3 & Reversed model & 18.82 & 9 & 0.983 & 0.956 & 0.089 & 1 vs. 3 & $21.57^{* *}$ & 3 \\
\hline \multirow[t]{4}{*}{4} & Reciprocal model & 4.19 & 6 & 1.000 & 1.000 & 0.000 & 1 vs. 4 & $8.58 *$ & 6 \\
\hline & & & & & & & 2 vs. 3 & $7.31 *$ & 0 \\
\hline & & & & & & & 2 vs. 4 & $7.81 *$ & 3 \\
\hline & & & & & & & 3 vs. 4 & $13.77^{* *}$ & 3 \\
\hline
\end{tabular}

${ }^{*} p<0.05,{ }^{* *} p<0.01, \chi^{2}$ : chi-square, CFI: comparative fit index, TLI: Tucker-Lewis index, RMSEA: root mean square error approximation, $\Delta \chi^{2}$ : chi-square difference, $\Delta \mathrm{df}$ : degrees of freedom.

The results in Table 5 show that the causality model's parameters have a significant autoregressive impact, indicating that the variables were largely stable over time $\left(\Delta \chi^{2}=7.81\right.$, (not significant). Among the competing models, the study found the causality model to be the best-fitting model (Table 5: $\Delta \chi^{2}=26.91, p<0.01$ ). The results support hypothesis 1 because there is a positive lagged effect of all stressors on the development of perceived entrepreneurial stress over time (Table 6: capability gap model 2: $\gamma=0.28, p<0.01$; achievement gap model 2: $\gamma=0.34, p<0.01$; social life gap model 2: $\gamma=0.27, p<0.01$ and stability gap model 2: $\gamma=0.35$ ). Further, the study accepted hypothesis 2 as the reversed model (Table 5: $\Delta \chi^{2}=21.57, p<0.01$ ) showed a good model fit. Finally, hypothesis 3 is also supported as the model showed a good model fit but was weakest among the competing models (Table 5: $\Delta \chi^{2}=8.58, p<0.05$ ).

Table 6. Parameter estimates of the path models.

\begin{tabular}{|c|c|c|c|c|}
\hline & \multicolumn{2}{|c|}{ Model 2: Causality Model } & \multicolumn{2}{|c|}{ Model 5: Moderation Model } \\
\hline & $\gamma$ & SE & $\gamma$ & SE \\
\hline \multicolumn{5}{|l|}{ Autoregressive effects } \\
\hline Capability gap & $0.59^{* *}$ & 0.05 & $0.71^{* *}$ & 0.03 \\
\hline Achievement gap & $0.71^{* *}$ & 0.03 & $0.77^{* *}$ & 0.02 \\
\hline Social life gap & $0.77^{* *}$ & 0.02 & $0.68^{* *}$ & 0.04 \\
\hline Stability gap & $0.68^{* *}$ & 0.04 & $0.47 * *$ & 0.06 \\
\hline Psycap & $0.47^{* *}$ & 0.06 & $0.66^{* *}$ & 0.05 \\
\hline Perceived entrepreneurial stress & $0.66^{* *}$ & 0.05 & $0.59 * *$ & 0.05 \\
\hline \multicolumn{5}{|l|}{ Predicting entrepreneurial stress (T2) } \\
\hline Capability gap (T1) & $0.28^{* *}$ & 0.05 & $0.59^{* *}$ & 0.05 \\
\hline Achievement gap (T1) & $0.34 * *$ & 0.03 & $0.71 * *$ & 0.03 \\
\hline Social life gap (T1) & $0.27^{* *}$ & 0.02 & $0.77^{* *}$ & 0.02 \\
\hline Stability gap (T1) & $0.35^{* *}$ & 0.04 & $0.68 * *$ & 0.04 \\
\hline Psycap (T1) & $-0.39^{* *}$ & 0.06 & $0.47^{* *}$ & 0.06 \\
\hline Capability Gap × Psycap (T1) & & & $-0.19 * *$ & 0.05 \\
\hline Achievement Gap $\times$ Psycap (T1) & & & $-0.26^{* *}$ & 0.04 \\
\hline Social Life Gap × Psycap (T1) & & & $-0.39 * *$ & 0.05 \\
\hline Stability Gap $\times$ Psycap $(\mathrm{T} 1)$ & & & $-0.14^{* *}$ & 0.02 \\
\hline
\end{tabular}

$$
\text { ** } p<0.01 \text {. }
$$

\subsection{Examination of the Moderating Effects of Psychological Capital}

Hypothesis 4 examined the moderation effect of psychological capital on perceived entrepreneurial stress. The predictor variables were calculated by multiplying the $\mathrm{z}$ standardized variables measured at T1. The study examined these interaction effects of capability gap, achievement gap, social life gap, stability gap, and PsyCap through the causality models since they showed the best model fit. 
The results of moderation tests in Figure 2 show the parameter estimates. The data fit the theorized model $\left(\chi^{2}(16)=12.92\right.$ n.s., $\mathrm{CFI}=0.981$; TLI $=0.983$; $\left.\mathrm{RMSEA}=0.04\right)$.

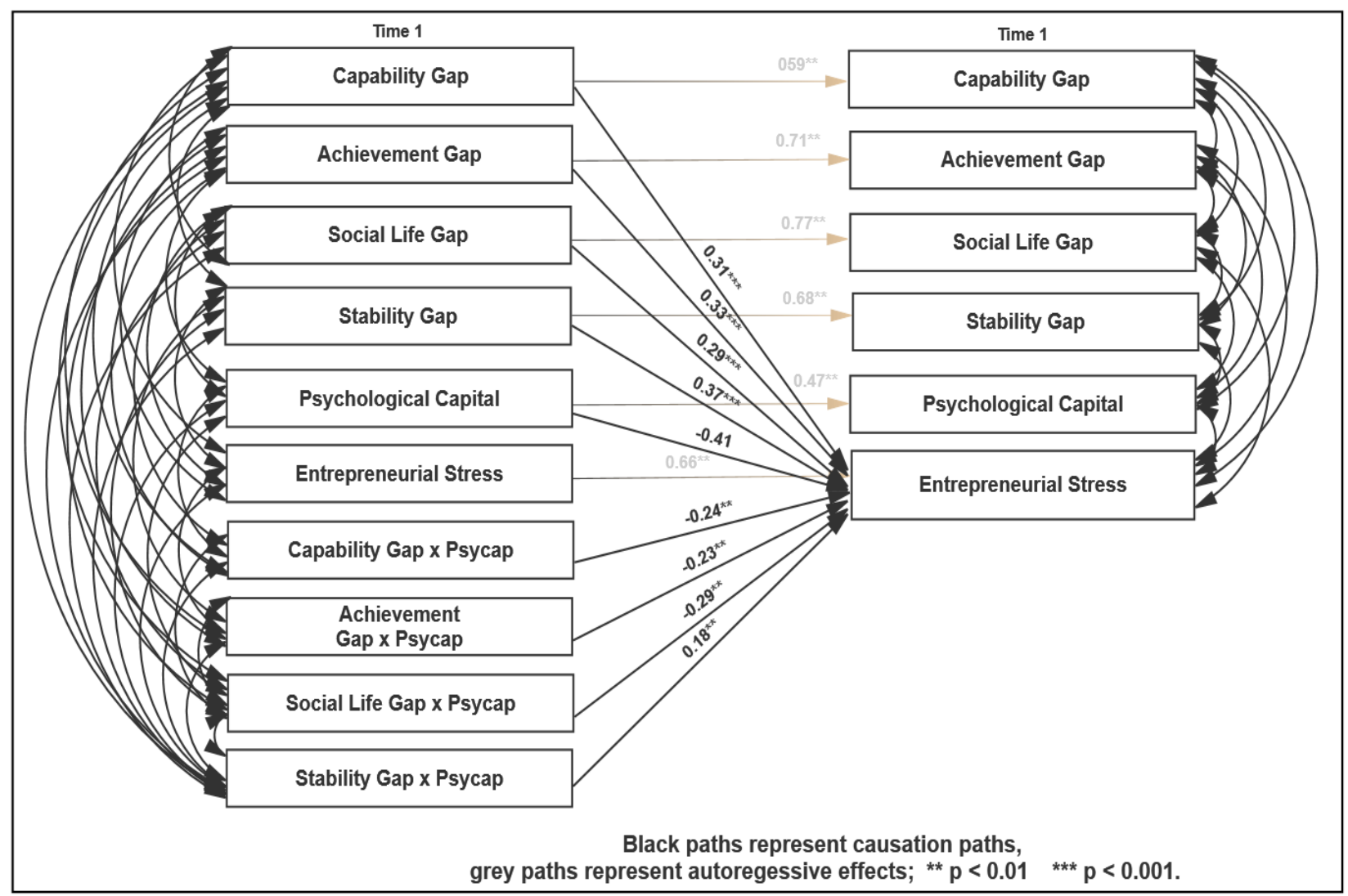

Figure 2. Parameter Estimates of Moderation Model (lagged effects).

The results indicate that PsyCap moderates the undesirable effect of stress predictors on entrepreneurial stress development over time. Hypothesis 4 is supported because the results reveal that the interaction of capability gap and PsyCap was negatively related to the change of entrepreneurial stress over time (Table 6: model 5: $\gamma=-0.19, p<0.01$; achievement gap and PsyCap model 5: $\gamma=-0.26, p<0.01$; social life gap and PsyCap model 5: $\gamma=-0.39, p<0.01$; and stability gap and PsyCap (model 5: $\gamma=0.14, p<0.01$ )).

Furthermore, Preacher et al. [102] suggested verifying the interacting effects through a slope analysis. The results show that when PsyCap is high, gaps in capabilities do not affect the change in PsyCap $(\gamma=-0.03$, n.s.). Similarly, under the conditions of strong PsyCap, disparities in capability, achievement, and stability did not affect the development of perceived entrepreneurial stress over time $(\gamma=-0.04$, n.s. $)(\gamma=-0.01$, n.s.). Contrariwise, under conditions of weak PsyCap, stress predictors adversely affect the development of perceived entrepreneurial stress $(\gamma=0.19, p<0.05)(\gamma=0.23, p<0.05)(\gamma=0.29, p<0.05)$. Thus, hypothesis 4 is fully supported.

\section{Discussion}

Stress is an accompaniment to all forms of employment. However, due to the nature of entrepreneurial jobs, stress among entrepreneurs is more prevalent. The study examined several stressors relevant to entrepreneurial jobs and life. Three major categories, namely personal, social, and occupational stressors, were posited to have causal and reciprocal impacts. The study confirmed that personal, social, and occupational stressors have a causal effect on PES. The study found that personal, social, and occupational stressors had a common underlying characteristic of "resource constraints" that create a "resource gap" in an entrepreneur's work and life. The study utilized the resource-based view theory 
to understand and explain PES. RBV emphasizes the role of resources and capabilities in developing value at both individual and organizational levels.

Entrepreneurs consider several intangible resources valuable to their work and life, and a perceived threat or loss of these resources causes PES. The complexity of stress is evident when PES also has a reversed effect on personal, social, and occupational stressors. Since perceptions mostly drive entrepreneurial stress, any variations in personal, social, and occupational resource gaps are likely to impact PES. Entrepreneurs may overestimate any adverse variations due to already formed perceptions of limitations and gaps in capabilities and resources. Therefore, in reverse causal impacts, stress' subjectivity will prevail over an objective evaluation of stress [26].

Further, the study found that stressors and PES exert mutual influences on each other over time. Although the reciprocal effect was not very strong, the bidirectional relationship showed that PES is a product and stress producer. The psychological feedback loop between stress as an outcome and stressors as capabilities and resource constraints constantly shifts and adjusts based on the entrepreneurs' perceptions [103].

Personal stressors relate to the entrepreneurial capabilities and expectations of goal achievements. An entrepreneur's capacity to control resources or predict outcomes leads to perceived entrepreneurial stress. An entrepreneur is expected to handle multiple job roles essential in entrepreneurial venturing, and thus creating capability limitations and, subsequently, PES [2]. As performance requirements intensify, actual and expected capability begins to widen, creating a resource gap that puts entrepreneurs under stress. Capability constraints compromise the achievement of personal, social, and occupational goals. The study argued that resource gaps could potentially undermine an entrepreneur's strategic capability to innovate. Innovation requires a stress-free cognitive mind and appropriate resource allocation. According to Qazi [104], entrepreneurial careers provide emotional satisfaction and are a source of meaningful lives. Contrary to their expectations, scarcity of time, money, and capability resources lead to undesirable outcomes [46]. As adverse circumstances intensify, resource gaps widen, leading to PES. Perceived stress in these situations would be due to "fear of negative social evaluation, fear of failure and loss of self-esteem" [105].

Due to the entrepreneur's immersion in their jobs and a blurred line between work and social life, an entrepreneur's social life quality is compromised. Their desire to be part of a social network is essential to relieving entrepreneurial jobs' pressure [106]. Further, as their work and social lives become intertwined, the quality of social life suffers compared to the entrepreneurs' perceived social life. Entrepreneurs feel restricted in the achievement of their personal, social and occupational goals. One such plan that is an entrepreneurial firm's priority is innovation.

The stability gap as a result of higher levels of risk-taking in an entrepreneurial job creates occupational stressors. Entrepreneurs work under risky conditions and have to make decisions under uncertainty. Prominent among them is the pressure to innovate to improve competitive strength. The tension in the environment and an inability to manage resources beyond their control become significant stressors [71]. As risks and uncertainty intensify, they take a toll on the entrepreneur's psychological wellbeing. They begin to desire stable conditions in their work and life. These risks are not only financial but also are related to their health and emotions [70]. Fatoki [107] pointed out that many a time, the risk and stability gap is so immense that the entrepreneur seriously considers quitting their job.

Entrepreneurial stress is psychologically driven, and hence, a psychological reaction is essential to counter its effects [90]. PsyCap is posited as psychological strength to deal with the adverse impacts of entrepreneurial stress. Despite capability limitations, self-efficacy enables entrepreneurs to believe and be confident in their capabilities to achieve performance goals. Resilience allows entrepreneurs to recover from setbacks and persevere in their course of action, even if it involves risky decisions in uncertain conditions. Entrepreneurs are also known to be quite resourceful, and through their resourcefulness, 
they can reduce gaps created through resource constraints. This includes finding time for friends and family, striving to enhance personal capabilities, and building systems and networks to cushion the effects of uncertain environments. Entrepreneurs with a more robust response through PsyCap are more effective in dealing with stress. These psychological capital elements can assist entrepreneurs in psychological detachment from the adverse effects of entrepreneurial stress [4].

\subsection{Contributions to Theory}

Paying heed to the call to contextualize RBV theory in entrepreneurship research [108], the study focuses on the relevance of resources in an entrepreneurial and emerging market context. The transference of resource-based perspectives to entrepreneurship literature enriches its understanding of entrepreneurial stress and coping methods. The study addresses some of the deficiencies of stress appraisal theory [8], which has considered stress subjective, and the onus of stress appraisal was put on the victim of stress. This study combines perceptual views with objective measures of resources to provide a more comprehensive view of entrepreneurial stress. The study's findings highlight the appropriateness of the intangible resources and capabilities in the context of the environment. Resource conceptualization in an entrepreneurial setting sheds light on several intangible resources considered valuable and non-substitutable by entrepreneurs. From a psychological standpoint, these intangible resources are perceived as useful as they enable entrepreneurs to conduct their businesses and life in the way they expected [4]. Consequently, when entrepreneurs cannot fill the presumed or actual loss of valuable resources, the situation creates PES [40].

\subsection{Practical Implications of the Study}

The study's findings have practical implications for several stakeholders. Firstly, entrepreneurs are expected to understand that stressors are part of the entrepreneurial experience and to be realistic in their expectations. An isolated view of entrepreneurial benefits without considering available resources and possible capabilities may lead to a stressful experience. Secondly, educators could consider examining the effect of challenge stressors and their potential impact on improving entrepreneurial motivation and wellbeing. Educators, trainers, and occupational psychologists can develop psychological strength to reduce any incursion on their psychological wellbeing. It should be understood that PsyCap cannot guarantee a "stressless" state, but through appropriate response, negative effects of stress can be moderated. If educators and researchers can capture the logic of entrepreneurial stress, by doing so, they can open the possibilities and constraints within which strategy practices are enacted. Entrepreneurs can be encouraged to leverage open innovation benefits, which can offset some of the effects of resource and capability limitations. Finally, policymakers in emerging markets can benefit from an enhanced understanding of entrepreneurial stress and possible avenues of mitigation, preventing entrepreneurs from quitting their businesses. Policymakers in these countries should ensure that resource gaps do not constrain entrepreneurial performance, particularly innovation. Creative ideas cannot emerge from clouded minds, and limited capabilities may restrict innovation activities.

\section{Conclusions}

This study addressed some of the gaps associated with entrepreneurial stress research. Perceptions of stress among entrepreneurs are generally linked to resources and capabilities. Such a linkage is probably because entrepreneurial jobs are typically known to be resource pressured, which become more sensitive in resource-constrained emerging markets. Past studies have not adequately adopted a resource-perspective in explaining entrepreneurial stress. Furthermore, those studies mostly considered tangible resources as valuable to entrepreneurs. Entrepreneurial jobs are complicated, and without a clear demarcation between work and personal and social lives, both tangible and intangible 
resources and individual capabilities become critical to entrepreneurial success. In contrast to an overwhelming focus on tangible resources in previous studies, this study adopted a softer approach in highlighting the crucial role of intangible resources and capabilities.

Analyzing entrepreneurial stress through a competing model framework and associated directional hypotheses helped make a causal interpretation of entrepreneurial stress. An assessment of causal, reverse, and reciprocal impacts through a longitudinal study design helped reconcile the complex nature of entrepreneurial stress. Entrepreneurs experience stress when their perceptions about entrepreneurial careers turn out to be contrary to their expectations due to resource and capability constraints. Gaps in intangible resources and capabilities create a perception of work and life's uncontrollability, leading to PES. Once the perception of resource limitations is formed, entrepreneurs become more vulnerable to stress through any stressors. Since stress is a psychological process, stressors and entrepreneurial stress mutually influence each other, adjusting perceptions of either work or life or resource gaps.

Personal, social, and occupational stressors are subject to volatility and uncertainty in emerging markets characterized by low institutional quality $[109,110]$. These economic and socio-cultural conditions are likely to influence the entrepreneur's perception of gaps and stress. Resource constraints in emerging markets further compromise entrepreneurial capabilities for innovation. Entrepreneurs in emerging markets can potentially harness the benefits of open innovation as they face global competition. Open innovation requires the utilization of internal and external resources, particularly the creative side of human thinking, which may be compromised under stressful conditions [111]. The perception of stress is subjective, but perceptual gaps can be reduced with an objective evaluation of resources and capabilities. One such capability that entrepreneurs can utilize is psychological capital. An ideal psychological response using psychological capital can help mitigate some of the adverse effects of perceived entrepreneurial stress.

\section{Limitations and Directions for Future Research}

The study's limitations relate to a smaller sample size, which does not fully represent all the emerging markets. The study could not fully establish the transferability and generalizability of the findings. A time lag of 12 months may provide limited insights, and hence, future studies could examine multiple time lags to study the evolving nature of stress. Future studies can also study the effects of entrepreneurial stress on the behavioral strain.

Author Contributions: Conceptualization, T.A.; V.R.; P.B., methodology, Q.K.; software, T.A., formal analysis, V.T., P.B., V.R.; investigation, all authors; data curation, T.A.; V.R., writing-review and editing, P.B., V.R., Q.K., T.A. and V.T. All authors have read and agreed to the published version of the manuscript.

Funding: This research received no external funding.

Institutional Review Board Statement: Not applicable.

Informed Consent Statement: Not applicable.

Data Availability Statement: Not applicable.

Acknowledgments: We would like to thank the Small and Medium Enterprise Development Authority (SMEDA) in Pakistan, chambers of commerce in RAK, Sharjah, and Dubai UAE, and the Micro-Enterprise Association in India for enabling the data collection.

Conflicts of Interest: The authors declare no conflict of interest.

\section{References}

1. Bliese, P.D.; Edwards, J.R.; Sonnentag, S. Stress and Wellbeing at Work: A Century of Empirical Trends Reflecting Theoretical and Societal Influences. J. Appl. Psychol. 2017, 102, 389-402. [CrossRef] [PubMed]

2. Cohen, S.; Janicki-Deverts, D. Who's stressed? Distributions of psychological stress in the United States in probability samples from 1983, 2006, and 2009. J. Appl. Soc. Psychol. 2012, 42, 1320-1334. [CrossRef] 
3. Gorgievski, M.J.; Stephan, U. Advancing the Psychology of Entrepreneurship: A Review of the Psychological Literature and an Introduction. Appl. Psychol. 2020, 65, 437-468. [CrossRef]

4. Eager, B.; Grant, S.; Maritz, A. Entrepreneurs and the stress-coping-strain process: How relevant are existing theoretical frameworks? In Proceedings of the Australian Centre for Entrepreneurship Research Exchange, ACERE 2015, Adelaide, Australia, 3-6 February 2015; pp. 251-265.

5. Shepherd, D.A. A Psychological Approach to Entrepreneurship: Selected Essays of Dean A. Shepherd; Edward Elgar Publishing: Cheltenham, UK, 2014.

6. Harkness, K.L.; Hayden, E.P. (Eds.) The Oxford Handbook of Stress and Mental Health; Oxford University Press: New York, NY, USA, 2020.

7. Lerman, M.P.; Munyon, T.P.; Williams, D.A. The (not so) Dark Side of Entrepreneurship: A Meta-Analysis of the Well-being and Performance Consequences of Entrepreneurial Stress. Strateg. Entrep. J. Spec. Issue 2020. [CrossRef]

8. Lazarus, R.S.; Folkman, S. Stress, Appraisal and Coping; Springer: New York, NY, USA, 1984.

9. Grant, S.; Ferris, K. Identifying Sources of Occupational Stress in Entrepreneurs for Measurement. Int. J. Entrep. Ventur. 2012, 4, 351-373. [CrossRef]

10. Prottas, D.J.; Thompson, C.A. Stress Satisfaction and Family Life Interface: A Comparison of Self-employed Business Owners, Independents, and Organizational Employees. J. Occup. Health Psychol. 2006, 11, 366-378. [CrossRef]

11. Wiklund, J.; Nikolaev, B.; Shir, N.; Foo, M.D.; Bradley, S. Entrepreneurship and wellbeing: Past, Present, and Future. J. Bus. Ventur. 2019, 34, 579-588. [CrossRef]

12. Shim, I.; Shin, K. Financial Stress in Lender Countries and Capital Outflows from Emerging Market Economies. Bank Int. Settl. Work. Pap. 2018, 745, 1-42.

13. Sharma, V. Forecasting Stock Index Volatility with GARCH Models: International Evidence. Stud. Econ. Financ. 2015, 32, 445-463. [CrossRef]

14. Kortum, E.; Leka, S.; Cox, T. Psychosocial Risks and Work-Related Stress in Developing Countries: Health Impact, Priorities, Barriers, and Solutions. Int. J. Occup. Med. Environ. Health 2010, 23, 225-238. [CrossRef]

15. Clough, D.R.; Fang, T.P.; Vissa, B.; Wu, A. Turning Lead Into Gold: How do Entrepreneurs Mobilize Resources to Exploit Opportunities? Acad. Manag. Ann. 2019, 13, 240-271. [CrossRef]

16. Kariv, D. The Relationship between Stress and Business Performance among Men and Women Entrepreneurs. J. Small Bus. Entrep. 2008, 21, 449-476. [CrossRef]

17. Su, X.; Liu, S.; Zhang, S.; Liu, L. To be Happy: A Case Study of Entrepreneurial Motivation and Entrepreneurial Process from the Perspective of Positive Psychology. Sustainability 2020, 12, 584. [CrossRef]

18. Wincent, J.; Örtqvist, D. A comprehensive model of entrepreneur role stress antecedents and consequences. J. Bus. Psychol. 2009, 24, 225-243. [CrossRef]

19. Hobfoll, S.E.; Halbesleben, J.; Neveu, J.P.; Westman, M. Conservation of Resources in the Organization Context: The Reality of Resources and their Consequences. Annu. Rev. Organ. Psychol. Organ. Behav. 2018, 5, 103-128. [CrossRef]

20. Cardon, M.S.; Patel, P.C. Is Stress Worth it? Stress-related Health and Wealth Trade-offs for Entrepreneurs. Appl. Psychol. 2015, 64, 379-420. [CrossRef]

21. Uy, M.A.; Foo, M.D.; Song, Z. Joint Effects of Prior Start-Up Experience and Coping Strategies on Entrepreneurs' Psychological Well-Being. J. Bus. Ventur. 2013, 28, 583-597. [CrossRef]

22. Desa, G.; Basu, S. Optimization or bricolage? Overcoming resource constraints in global social entrepreneurship. Strateg. Entrep. J. 2013, 7, 26-49. [CrossRef]

23. Naik, B.A. Entrepreneurial Role Stress among Women Working in Mahila Bachat Gat (Women self-help group). Gold. Res. Thoughts 2012, 1, 1-10.

24. Barney, J.B. Is the Resource-based "View" a Useful Perspective for Strategic Management Research? Yes. Acad. Manag. Rev. 2001, $26,41-56$.

25. Nason, R.S.; Wiklund, J. An Assessment of Resource-based Theorizing on Firm Growth and Suggestions for the Future. J. Manag. 2018, 44, 32-60. [CrossRef]

26. Frese, M. Stress at work and psychometric complaints: A causal interpretation. J. Appl. Psychol. 1983, 70, 314-328. [CrossRef]

27. Tahseen, A.A.; Burns, P. Designing an Organization for Innovation in Emerging Economies: The Mediating Role of Readiness for Innovation. Organ. Mark. Emerg. Econ. 2019, 10, 31-56.

28. Nazlioglu, S.; Soytas, U.; Gupta, R. Oil Prices and Financial Stress: A Volatility Spill-over Analysis. Energy Policy 2015, 82, 278-288. [CrossRef]

29. Kumar, R.; Raj, T. Role of Entrepreneurship in Boosting Economic Growth and Employment in India. SEDME Small Enterp. Dev. Manag. Ext. J. 2019, 46, 273-281.

30. Saberi, M.; Hamdan, A. The Moderating Role of Governmental Support in the Relationship between Entrepreneurship and Economic Growth: A Study on the GCC Countries. J. Entrep. Emerg. Econ. 2019, 11, 200-216. [CrossRef]

31. Barney, J.B.; Ketchen, D.J.; Wright, M. The Future of Resource-Based Theory. J. Manag. 2011, 37, 1299-1315. [CrossRef]

32. Barney, J.B. Measuring Firm Performance in a Way that Is Consistent with Strategic Management Theory. Acad. Manag. Discov. 2020, 6, 5-7. [CrossRef] 
33. Morris, M.H.; Kuratko, D.F.; Allen, J.W.; Ireland, R.D.; Schindehutte, M. Resource Acceleration: Extending Resource-based Theory in Entrepreneurial Ventures. J. Appl. Manag. Entrep. 2010, 15, 4-25.

34. Collins, C.J. Expanding the resource-based view model of strategic human resource management. Int. J. Hum. Resour. Manag. 2020, 1-28. [CrossRef]

35. Sameera, K.P. Do resource-based view spur firm performance: A literature review. Int. J. Nov. Res. Humanit. Soc. Sci. 2020, 7, 45-51. [CrossRef]

36. Barney, J.B.; Arikan, A.M. The Resource-Based View: Origins and Implications. In The Blackwell Handbook of Strategic Management; Blackwell Publishers: Oxford, UK, 2001.

37. Crook, T.R.; Ketchen, D.J., Jr.; Combs, J.G.; Todd, S.Y. Strategic Resources and Performance: A Meta-analysis. Strateg. Manag. J. 2008, 29, 1141-1154. [CrossRef]

38. Alonso, D. Exploring a developing tourism industry: A resource-based view approach. Tour. Recreat. Res. 2017, 42, 45-48.

39. Perry-Rivers, P. Stratification, Economic Adversity, and Entrepreneurial Launch: The Effect of Resource Position on Entrepreneurial Strategy: ET\&P. Entrep. Theory Pract. 2016, 40, 685-712.

40. Rauch, A.; Fink, M.; Hatak, I. Stress Processes: An Essential Ingredient in the Entrepreneurial Process. Acad. Manag. Perspect. 2018, 32, 340-357. [CrossRef]

41. Stephan, U. Entrepreneurs' Mental Health and Well-being: A Review and Research Agenda. Acad. Manag. Perspect. 2018, 32, 290-322. [CrossRef]

42. Monroe, S.M.; Slavich, G.M. Psychological Stressors: Overview, in Stress: Concepts, Cognition, Emotion, and Behaviour, 1st ed.; Fink, G., Ed.; Academic Press: Cambridge, MA, USA, 2016; pp. 109-115.

43. Aure, P.A.H.; Dui, R.P.; Jimenez, S.V.; Daradar, D.D.; Gutierrez, A.N.A.; Blasa, A.C.; Sy-Changco, J. Understanding social entrepreneurial intention through social cognitive career theory: A partial least squares structural equation modeling approach. Organ. Mark. Emerg. Econ. 2019, 10, 92-110. [CrossRef]

44. Tran, A.T.; Von Korflesch, H. A Conceptual Model of Social Entrepreneurial Intention Based on the Social Cognitive Career Theory. Asia Pac. J. Innov. Entrep. 2016, 10, 17-38. [CrossRef]

45. Tahir, U. Entrepreneurial Stress in SMEs. J. Resour. Dev. Manag. 2016, 18, 51-64.

46. Ebbers, J.J.; Wijnberg, N.M. Betwixt and Between Role Conflict, Role Ambiguity and Role Definition in Project-Based DualLeadership Structures. Hum. Relat. 2017, 70, 1342-1365. [CrossRef]

47. Baikadi, S.B. Ordered Thinking Versus Disordered Doing: A study of Entrepreneurial Role Stress in the Ethiopian Business Environment. J. Econ. Dev. Manag. ITFinanc. Mark. 2016, 8, 24.

48. Mathias, B.D.; Williams, D.W. Giving up the hats? Entrepreneurs' Role Transitions and Venture Growth. J. Bus. Ventur. 2018, 33, 261-277. [CrossRef]

49. Lechat, T.; Torrès, O. Stressors and satisfactors in entrepreneurial activity: An event-based, mixed methods study predicting small business owners' health. Int. J. Entrep. Small Bus. 2017, 32, 537-569. [CrossRef]

50. Wincent, J.; Örtqvist, D. Role Stress and Entrepreneurship Research. Int. Entrep. Manag. J. 2009, 5, 1-22. [CrossRef]

51. McMullen, J.S.; Shepherd, D.A. Entrepreneurial Action and the Role of Uncertainty in the Theory of the Entrepreneur. Acad. Manag. Rev. 2006, 31, 132-152. [CrossRef]

52. Mol, E.; Ho, V.T.; Pollack, J.M. Predicting Entrepreneurial Burnout in a Moderated Mediated Model of Job Fit. J. Small Bus. Manag. 2018, 56, 392-411. [CrossRef]

53. Cardon, M.S.; Gregoire, D.A.; Stevens, C.E.; Patel, P.C. Measuring Entrepreneurial Passion: Conceptual Foundations and Scale Validation. J. Bus. Ventur. 2013, 28, 373-396. [CrossRef]

54. Burns, P. Entrepreneurship and Small Business; Palgrave McMillan: London, UK, 2018.

55. Jayawarna, D.; Rouse, J.; Kitching, J. Entrepreneur Motivations and Life Course. Int. Small Bus. J. 2013, 31, 34-56. [CrossRef]

56. McGowan, P.; Redeker, C.L.; Cooper, S.Y.; Greenan, K. Female Entrepreneurship and the Management of Business and Domestic Roles: Motivations, Expectations and Realities. Entrep. Reg. Dev. 2012, 24, 53-72. [CrossRef]

57. Chan, C. Border Crossing: Work-Life Balance Issues with Chinese Entrepreneurs in New Zealand. Ph.D. Thesis, Auckland University of Technology, Auckland, New Zealand, 2008.

58. Cocker, F.; Martin, A.; Scott, J.; Venn, A.; Sanderson, K. Psychological distress, related work attendance, and productivity loss in small-to-medium enterprise owner/managers. Int. J. Environ. Res. Public Health 2013, 10, 5062-5082. [CrossRef]

59. Fernet, C.; Austin, S.; Trépanier, S.G.; Dussault, M. How do job characteristics contribute to burnout? Exploring the distinct mediating roles of perceived autonomy, competence, and relatedness. Eur. J. Work Organ. Psychol. 2013, 22, 123-137. [CrossRef]

60. Wakker, P.P. Prospect Theory: For Risk and Ambiguity; University Press: Cambridge, UK, 2010.

61. Toyin, A.A.; Gbadamosi, G.; Mordi, T.; Mordi, C. In Search of Perfect Boundaries? Entrepreneurs' Work-life Balance. Pers. Rev. $\mathbf{2 0 1 9}, 48,1634-1651$.

62. Helmle, J.R.; Botero, I.C.; Seibold, D.R. Factors that Influence Perceptions of Work-life Balance in Owners of Copreneurial Firms. J. Fam. Bus. Manag. 2014, 4, 110-132. [CrossRef]

63. Keyes, C.L. Subjective Wellbeing in Mental health and Human Development Research Worldwide: An Introduction. Soc. Indic. Res. 2006, 77, 1-10. [CrossRef]

64. Overla, M.D. The Explanatory Relationship between Work-Life Balance and Non-Work Factors of Entrepreneurs. Ph.D. Thesis, Capella University, Minneapolis, MN, USA, 2017. 
65. Koe, W.L. The Motivation to Adopt E-Commerce among Malaysian Entrepreneurs. Organ. Mark. Emerg. Econ. 2020, 11, 189-202.

66. Semerci, A.B. The Effect of Social Support on Job Stress of Entrepreneurs. Acad. Entrep. J. 2016, $22,41$.

67. Nguyen, H.; Sawang, S. Juggling or Struggling? Work and Family Interface and its Buffers among Small Business Owners. Entrep. Res. J. 2016, 6, 207-246. [CrossRef]

68. Spicka, J. Socio-demographic drivers of the risk-taking propensity of micro farmers: Evidence from the Czech Republic. J. Entrep. Emerg. Econ. 2020, 12, 569-590. [CrossRef]

69. Fernet, C.; Torrès, O.; Austin, S.; St-Pierre, J. The psychological costs of owning and managing an SME: Linking job stressors, occupational loneliness, entrepreneurial orientation, and burnout. Burn. Res. 2016, 3, 45-53. [CrossRef]

70. Gardoni, P.; Murphy, C. A Scale of Risk. Risk Anal. 2014, 34, 1208-1227. [CrossRef]

71. Omrane, A.; Kammoun, A.; Seaman, C. Entrepreneurial Burnout: Causes, Consequences and Way Out. FIIB Bus. Rev. 2018, 7, 28-42. [CrossRef]

72. Barney, J. Gaining Sustainable Competitive Advantage; Prentice-Hall: Upper Saddle River, NJ, USA, 2007.

73. Bogodistov, Y.; Wohlgemuth, V. Enterprise risk management: A capability-based perspective. J. Risk Financ. 2017, 18, 234-251. [CrossRef]

74. Rabenu, E.; Yaniv, E.; Elizur, D. The relationship between psychological capital, coping with stress, wellbeing, and performance. Curr. Psychol. 2017, 36, 875-887. [CrossRef]

75. Baron, R.A.; Franklin, R.J.; Hmieleski, K.M. Why entrepreneurs often experience low, not high, levels of stress: The joint effects of selection and psychological capital. J. Manag. 2016, 42, 742-768. [CrossRef]

76. Jensen, S.M. Psychological Capital: Key to Understanding Entrepreneurial Stress. Econ. Bus. J. Inq. Perspect. 2012, 4, 44-55.

77. Peterson, S.J.; Luthans, F.; Avolio, B.J.; Walumbwa, F.O.; Zhang, Z. Psychological Capital and Employee Performance: A Latent Growth Modelling Approach. Pers. Psychol. 2011, 64, 427-450. [CrossRef]

78. Avey, J.B.; Luthans, F.; Jensen, S.M. Psychological Capital: A Positive Resource for Combating Employee Stress and turnover. Hum. Resour. Manag. 2009, 48, 677-693. [CrossRef]

79. Luthans, F.; Avolio, B.J.; Avey, J.B.; Norman, S.M. Positive psychological capital: Measurement and relationship with performance and satisfaction. Pers. Psychol. 2007, 60, 541-572. [CrossRef]

80. Kamal, S.; Daoud, Y.S. Do country level constructs affect the relation between self-efficacy and fear of failure? J. Entrep. Emerg. Econ. 2020, 12, 545-568. [CrossRef]

81. Salisu, I.; Hashim, N.; Mashi, M.S.; Aliyu, H.G. Perseverance of effort and consistency of interest for entrepreneurial career success: Does resilience matter? J. Entrep. Emerg. Econ. 2020, 12, 279-304. [CrossRef]

82. Reivich, K.; Shatté, A. The Resilience Factor: 7 Essential Skills for Overcoming Life's Inevitable Obstacles; Random House: New York, NY, USA, 2002.

83. Heilbrunn, S. Against all Odds: Refugees Bricoleuring in the Void. Int. J. Entrep. Behav. Res. 2019, 25, 1045-1064. [CrossRef]

84. Welter, F.; Xheneti, M.; Smallbone, D. Entrepreneurial Resourcefulness in Unstable Institutional Contexts: The Example of European Union Borderlands. Strateg. Entrep. J. 2018, 12, 23-53. [CrossRef]

85. Hair, J.F.; Anderson, R.E.; Babin, B.J.; Black, W.C. Multivariate Data Analysis: A Global Perspective, 7th ed.; MacMillan: New York, NY, USA, 2010.

86. Rosseel, Y. Lavaan: An R Package for Structural Equation Modelling and more. Version 0.5-12 (BETA). J. Stat. Softw. 2012, 48, 1-36. [CrossRef]

87. Cohen, S.; Kamarck, T.; Mermelstein, R. A global measure of perceived stress. J. Health Soc. Behav. 1983, 24, 386-396. [CrossRef]

88. Lang, J.W.; Fries, S. A revised 10-item version of the Achievement Motives Scale. Eur. J. Psychol. Assess. 2006, 22, 216-224. [CrossRef]

89. Hammer, L.B.; Kossek, E.E.; Yragui, N.L.; Bodner, T.E.; Hanson, G.C. Development and validation of a multidimensional measure of family supportive supervisor behaviours (FSSB). J. Manag. 2009, 35, 837-856.

90. Luthans, F.; Avolio, B.J.; Avey, J.B. Psychological Capital Questionnaire: Manual Development, Applications, and Research; Mind Garden Inc.: Menlo Park, CA, USA, 2014.

91. Baruch, Y.; Holtom, B.C. Survey Response Rate Levels and Trends in Organizational Research. Hum. Relat. 2008, 61, 1139-1160. [CrossRef]

92. Hakanen, J.J.; Schaufeli, W.B.; Ahola, K. The Job Demands-Resources model: A Three-Year Cross-Lagged Study of Burnout, Depression, Commitment, and Work Engagement. Work Stress 2008, 22, 224-241. [CrossRef]

93. Draugalis, J.R.; Coons, S.J.; Plaza, C.M. Best Practices for Survey Research Reports: A Synopsis for Authors and Reviewers. Am. J. Pharm. Educ. 2008, 72, 11-12. [CrossRef]

94. Selig, J.P.; Little, T.D. Autoregressive and Cross-Lagged Panel Analysis for Longitudinal Data. In Handbook of Developmental Research Methods; Laursen, B., Little, T.D., Card, N.A., Eds.; The Guilford Press: New York, NY, USA, 2012; pp. $265-278$.

95. Baron, R.M.; Kenny, D.A. The Moderator-Mediator Variable Distinction in Social Psychological Research: Conceptual, Strategic, and Statistical Considerations. J. Personal. Soc. Psychol. 1986, 51, 1173. [CrossRef]

96. Hu, L.T.; Bentler, P.M. Cutoff Criteria for fit Indexes in Covariance Structure Analysis: Conventional Criteria Versus New Alternatives. Struct. Equ. Model. Multidiscip. J. 1999, 1, 1-55. [CrossRef]

97. Kenny, D.A.; Kaniskan, B.; McCoach, D.B. The Performance of RMSEA in Models with Small Degrees of Freedom. Sociol. Methods Res. 2015, 44, 486-507. [CrossRef] 
98. Tabachnick, B.G.; Fidell, L.S.; Ullman, J.B. Using Multivariate Statistics; Pearson: Boston, MA, USA, 2007; Volume 5, pp. 481-498.

99. Hamsici, O.C.; Martinez, A.M. Spherical-Homoscedastic Distributions: The Equivalency of Spherical and Normal Distributions in Classification. J. Mach. Learn. Res. 2007, 8, 1583-1623.

100. Holgado-Tello, F.; Chacón-Moscoso, S.; Sanduvete-Chaves, S.; Pérez-Gil, J.A. A simulation study of threats to validity in quasi-experimental designs: Interrelationship between design, measurement, and analysis. Front. Psychol. 2016, 7, 897. [CrossRef]

101. Kline, R.B. Principles and Practice of Structural Equation Modelling; Guilford Publications: New York, NY, USA, 2015.

102. Preacher, K.J.; Curran, P.J.; Bauer, D.J. Computational tools for probing interactions in multiple linear regression, multilevel modelling, and latent curve analysis. J. Educ. Behav. Stat. 2006, 31, 437-448. [CrossRef]

103. Tang, K. A reciprocal interplay between psychological stressors and worker wellbeing: A systematic view of reversed effects. Scand. J. Work Environ. Health 2014, 40, 451-456. [CrossRef]

104. Qazi, K. Making competitiveness more meaningful-A practice approach. In Proceedings of the British Academy of Management (BAM), Annual Conference: Thriving in Turbulent Times, Newcastle University, Newcastle upon Tyne, UK, 6-8 September 2016.

105. Cox, R.H. Sports Psychology_Concepts and Applications; McGraw-Hill: New York, NY, USA, 2007.

106. Boohene, R.; Gyimah, R.A.; Osei, M.B. Social capital and SME performance: The moderating role of emotional intelligence. J. Entrep. Emerg. Econ. 2019, 12, 79-99. [CrossRef]

107. Fatoki, O. Entrepreneurial Stress, Burnout, Intention to Quit, and Performance of an Immigrant-Owned Small Business in South Africa. Int. J. Entrep. 2019, 23, 1-15.

108. Sonnentag, S.; Fritz, C. Recovery from Job Stress: The Stressor-Detachment Model as an Integrative Framework. J. Organ. Behav. 2015, 36, 72-103. [CrossRef]

109. Siqueira, A.C.O.; Bruton, G.D. High-technology Entrepreneurship in Emerging Economies: Firm Informality and Contextualization of Resource-Based Theory. IEEE Trans. Eng. Manag. 2010, 57, 39-50. [CrossRef]

110. Vuong, Q.H.; Do, T.H.; Vuong, T.T. Resources, experience, and perseverance in entrepreneurs' perceived likelihood of success in an emerging economy. J. Innov. Entrep. 2016, 5, 1-24. [CrossRef]

111. Shan, B.; Cai, L.; Hatfield, D.E.; Tang, S. The Relationship Between Resources and Capabilities of New Ventures in Emerging Economies. Inf. Technol. Manag. 2014, 15, 99-108. [CrossRef] 